\title{
Quality of life related to health for heart failure patients
}

\author{
Qualidade de vida relacionada à saúde em pacientes com insuficiência cardíaca \\ Calidad de vida relacionada con la salud de pacientes con insuficiencia cardíaca
}

\section{Larissa Ferreira de Araújo Paz' ORCID: 0000-0003-4569-5080}

Carolina de Araújo Medeiros' ORCID: 0000-0002-8681-3285

Silvia Marinho Martins Alves' ORCID: 0000-0002-3093-9743

Simone Maria Muniz da Silva Bezerra' ORCID: 0000-0002-6301-8457

Wilson de Oliveira Junior' ORCID: 0000-0002-0178-5589

Maria Beatriz Araújo Silva' ORCID: 0000-0002-5730-5425

'Universidade de Pernambuco. Recife, Pernambuco, Brazil.

How to cite this article:

Paz LFA, Medeiros CA, Alves SMM, Bezerra SMMS, Oliveira Jr W, Silva MBA. Quality of life related to health for heart failure patients.

Rev Bras Enferm. 2019;72(Suppl 2):140-6. doi: http://dx.doi.org/10.1590/0034-7167-2018-0368

Corresponding Author: Larissa Ferreira de Araújo Paz E-mail: larissafaraujopaz@hotmail.com

Submission: 06-09-2018 Approval: 12-18-2018

\begin{abstract}
Objective: To assess the quality of life related to health for heart failure patients and to relate sociodemographic and clinical data. Method: It is an observational and transversal study, with quantitative approach, carried out in a heart failure ambulatory in the state of Pernambuco. Results: In the sample $(n=101)$, there was prevalence of men older than 60 years old, married and professionally inactive. The quality of life related to health, based on the Minnesota Living With Heart Failure Questionnaire, was considered moderate $(34.3 \pm 21.6)$, being significantly related to age $(p=0.004)$, functional class $(p<0.001)$, and patients with chagasic cardiopathy $(p=0.02)$. Conclusion: The quality of life in the HF group of chagasic etiology was more compromised, specially in the emotional dimension. It is suggested that studies on the hypothesis that longer ambulatory follow-up improves quality of life and that having Chagas disease interferes negatively with the quality of life of heart failure patients.

Descriptors: Quality of Life; Heart Failure; Ambulatory Assistance; Chagas Disease; Nursing.
\end{abstract}

\section{RESUMO}

Objetivo: Avaliar a qualidade de vida relacionada à saúde dos pacientes com insuficiência cardíaca e relacionar aos dados sociodemográficos e clínicos. Método: Trata-se de estudo observacional, de corte transversal, com abordagem quantitativa realizado em ambulatório de insuficiência cardíaca no estado de Pernambuco. Resultados: Na amostra $(n=101)$ houve predominância de homens, maiores de 60 anos, casados, profissionalmente inativos. A qualidade de vida relacionada à saúde, a partir do questionário Minnesota Living With Heart Failure Questionnaire foi considerada moderada $(34,3 \pm 21,6)$, apresentando relação significativa com idade $(p=0,004)$, classe funcional $(p<0,001)$ e em pacientes com cardiopatia chagásica $(p=0,02)$. Conclusão: A qualidade de vida no grupo IC de etiologia chagásica esteve mais comprometida, especialmente na dimensão emocional. Sugere-se a realização de estudos abordando as hipóteses de que maior tempo de acompanhamento ambulatorial melhora a qualidade de vida e que ter doença de Chagas interfere negativamente na qualidade de vida de pacientes com insuficiência cardíaca.

Descritores: Qualidade de Vida; Insuficiência Cardíaca; Assistência Ambulatorial; Doença de Chagas; Enfermagem.

\section{RESUMEN}

Objetivo: Evaluar la calidad de vida relacionada con la salud de los pacientes con insuficiencia cardíaca (IC) y relacionar los datos sociodemográficos y clínicos. Método: Se trata de estudio observacional, de corte transversal, con abordaje cuantitativo realizado en Ambulatorio de insuficiencia cardíaca en el estado de Pernambuco. Resultados: En la muestra $(n=101)$ hubo un predominio de hombres, mayores de 60 años de edad, casados y profesionalmente inactivos. La calidad de vida relacionada con la salud, desde el cuestionario Minnesota Living With Heart Failure Questionnaire, fue moderada $(34,3 \pm 21,6)$, presentando una relación significativa con la edad $(p=0,004)$, la clase funcional $(p<0,001)$ y en pacientes con cardiopatía chagásica $(p=0,02)$. Conclusión: La calidad de vida en el grupo IC de etiología chagásica estuvo más comprometida, principalmente la dimensión emocional. Se recomienda realizar estudios que aborden las hipótesis de que el mayor tiempo de seguimiento ambulatorio mejora la calidad de vida y de que tener la enfermedad de Chagas interfiere negativamente en la calidad de vida de pacientes con insuficiencia cardíaca.

Descriptores: Calidad de Vida; Insuficiencia Cardíaca; Atención Ambulatoria; Enfermedad de Chagas; Enfermería. 


\section{INTRODUCTION}

Considered a epidemy in progression, heart failure (HF) is defined as a clinic syndrome characterized by the disfunction in heart structure and functioning, preventing the necessary blood to be pumped to meet the organism's metabolic and tissue needs ${ }^{(1)}$.

Between 2013 and 2014, the disease was responsible for 460,813 hospitalizations in Brazil, a fact that may be related to the increasing population ageing and the high life expectation, which, along with the optimization of clinical treatment, contributes to the increase and prevalence of the disease ${ }^{(2)}$.

Due to high hospitalization rates, mortality levels, and economic and social costs, the disease is considered a challenging public health issue ${ }^{(1)}$. According to a Brazilian study, the most prevailing etiologies in HF are ischemic (30.3\%), hypertensive (20.4\%), idiopathic (14.5\%), valve (12.4\%) and, later on, chagasic ones $(10.8 \%)^{(3)}$.

The New York Heart Association (NYHA) classifies HF according to the intensity of the symptoms into four functional classes (FC), stablishing the patient's level of physical commitment during the performance of daily life activities and exercises ${ }^{(4)}$.

Clinical manifestations, as edema, dyspnea, and decrease of tolerance to daily life activities, associated to the disease' prolonged course and complexity, affect not only biological aspects, but also social, psychological, and spiritual aspects of HF patients, interfering systematically with their quality of life (QL) and well-being ${ }^{(5)}$.

The concern with the individuals' QL has been highlighted in the Health Sciences area. The definition and coverage of the concept of quality of life related to health (QLRH) are considered measures that quantify the patients' perception on the disease's functional effects and of the treatment on different aspects of life, considering the subjectivity of the physical, emotional, and social dimensions ${ }^{(6)}$.

The interest in monitoring QLRH is growing, given its importance as a prognostic indicator for morbidity and mortality, being recognized as a public health indicator ${ }^{(7)}$. Knowing that $\mathrm{HF}$ is a debilitating disease that compromises not only daily life activities, but also psychological and social aspects, and interferes directly with the quality of life related to the patients' health, measuring these damages will provide important information in order to improve the work of the multi-professional team, aiming to improve patients' adaptation and, consequently, the quality of life of this population.

\section{OBJECTIVE}

To assess the quality of life related to the health of heart failure patients and to relate it to sociodemographic and clinical data.

\section{METHOD}

\section{Ethical aspects}

This research complies to the Resolution $466 / 2012$ by the National Council of Health of the Ministry of Health and it was approved by the Committee of Research Ethics of the Oswaldo Cruz University Hospital (HUOC/PROCAPE).

\section{Study design, place, and period}

It is a observational and transversal study, with quantitative approach, carried out between November and December 2017 in the Chagas Disease and Heart Failure Ambulatory of Pernambuco, associated to the Cardiological University Medical Center Luís Tavares (PROCAPE/UPE).

\section{Population or sample: inclusion and exclusion criteria}

108 patients were invited to take part in the study, they were older than 18 years old, male and female, diagnosed with HF in ambulatory follow-up. Among the assessed patients, four were excluded for presenting neurological diseases (1), for refusing to participate (1) and due to locomotion difficulties (2). Therefore, the non-probabilistic convenience sample was composed by 101 patients.

\section{Study protocol}

The patients were invited to participate in the research while waiting for medical attendance and signed an Informed Consent Form. Sociodemographic and economic data were collected by an interview in a own tool and clinical information were collected by the Patient's Electronic Record (PER).

Among the variables analyzed, it was considered as independent variables the sociodemographic, economic and clinical data, such as: age, gender, race/color, precedence, marital status, schooling level, job, income per capita, costs with transportation to the ambulatory, costs with medicines per month, time since the HF diagnosis, etiology, functional class, ejection fraction, all medicines, and cardiological medicines. The age was dichotomized into younger and older than 60 years old. The functional class was analyzed into four categories and determined in the collection through the Specific Activity Scale (SAS).

With the intention of evaluating the QLRH of HF patients, the Minnesota questionnaire was used, which was translated into Portuguese and validated in $2009^{(8)}$. This tool evaluates the patients' perception in physical and emotional aspects related to $\mathrm{HF}$ through 21 items with a 0 to 5 answer scale.

The total score ranges from 0 to 105 , given that the best $Q L$ is associated with lower scores. Scores up to $<24$ points indicate good $\mathrm{QL}$, scores between 24 and 45 indicate moderate QL, and above 45, bad $\mathrm{QL}^{(9)}$. The items are subdivided into three dimensions and are related to physical difficulties (questions no. 1 to 7,12 , and 13); as well as emotional ones (questions no. 17 to 21); and general aspects, involving the items related to financial considerations, side effects of medicines and lifestyles (questions no. 8 to 11 , and 14 to 16$)^{(1)}$.

\section{Result analysis and statistics}

The data were stored in the Microsoft Excel 2013 program and analyzed in the statistical software Statistical Package for the Social Sciences (SPSS) for Windows version 21.0. The descriptive statistics of the quantitative variables were presented as averages, minimum and maximum standard-deviation, and variance. Categorical variables were presented in their absolute and relative frequencies. 
To compare the groups in relation to qualitative variables, the Pearson's Chi-Square test or Fisher's exact test were used, when needed. For quantitative variables, the Student's T test was used in cases that the normality distribution was not rejected. Otherwise, the non-parametric Mann-Whitney test was applied. It was performed the analysis of average differences between the Minnesota scale and the physical and emotional dimensions by the ANOVA test. The confidence interval used was $95 \%$ and the assumed significance level was $p<0.05$.

\section{RESULTS}

The sample was comprised by 101 patients in ambulatory care. There was prevalence of man, who were older than 60 years old, married, and had studied until elementary school, according to Table 1.

According to the data in Table $2, \beta$-blockers, ACE inhibitors/ARBs, and diuretics are the most used medicine classes. Among the interviewed patients, six $(5.9 \%)$ had pacemakers and one $(0.9 \%)$ had a cardiac resynchronizer.

The QL average and dimensions analyzed were considered moderate (34.3 \pm 21.6$)$ and, according to the data in Table 3, which related the total Minnesota scores to the QLRH classification, it is possible to see statistically significant relations stablished among FC, age, and chagasic HF (Chagas HF).

By analyzing sociodemographic, economic, and clinical variables with the Minnesota dimensions, it was observed a significant influence of jobs over physical dimensions and the total QLRH score. Economically active patients had better QL perceptions, and the FC variable was significant for both analyzed dimensions (physical and emotional) and for the total score. The scores were higher among patients with Chagas HF, with the emotional dimension as the aspect that affected bad QL perceptions the most (Table 4).

Despite not having identified significant differences between QLRH and race, marital status, monthly costs with medication, time being cared for in the ambulatory, and EF, black patients had worse numbers in the total QLRH score (38.8 20.4$)$, when compared to self-declared white patients (30.5 \pm 17.3$)$.

Similar results were observed for divorced patients (40.3 \pm 22.8 ) as well as married ones (33.8 \pm 21.4 ); with costs surpassing 200.00 Reais on medication/ month $(38.3 \pm 21.4)$, and for those with no costs (21.8 \pm 21.2$)$; among the patients who had being cared for less than 1 year in the ambulatory $(64.0 \pm 21.2)$ in relation to the ones going to the ambulatory for more then one year $(32.7 \pm 22.4)$; and those with reduced FE (38.0 \pm 19.3$)$ when compared to the ones with preserved FE (29.3 \pm 31.7$)$.
Table 1 - Sociodemographic and economic data of heart failure patients, Recife, Pernambuco, Brazil, 2017

\begin{tabular}{|c|c|c|c|c|}
\hline \multicolumn{2}{|c|}{ Sociodemographic Variables } & \multirow{2}{*}{$\begin{array}{c}\text { Average } \pm \text { SD } \\
60,23 \pm 10,81\end{array}$} & \multirow{2}{*}{$\begin{array}{c}\text { Minimum/ } \\
\text { maximum }\end{array}$} & \multirow{2}{*}{$\begin{array}{c}\mathbf{n}(\%) \\
53(52.5) \\
48(47.5)\end{array}$} \\
\hline Age & $\begin{array}{l}\geq 60 \text { years } \\
<60 \text { years }\end{array}$ & & & \\
\hline Gender & $\begin{array}{l}\text { Male } \\
\text { Female }\end{array}$ & & & $\begin{array}{l}57(56.4) \\
44(43.6)\end{array}$ \\
\hline Race/Color & $\begin{array}{l}\text { Brown } \\
\text { Black } \\
\text { White } \\
\text { Yellow }\end{array}$ & & & $\begin{array}{c}66(65.3) \\
19(18.8) \\
15(14.9) \\
1(1)\end{array}$ \\
\hline Marital status & $\begin{array}{l}\text { Married } \\
\text { Single } \\
\text { Widow(er) } \\
\text { Divorced }\end{array}$ & & & $\begin{array}{l}58(57.4) \\
19(18.8) \\
16(15.8) \\
8(7.9)\end{array}$ \\
\hline Precedence & $\begin{array}{l}\text { Metropolitan Region } \\
\text { Other Regions }\end{array}$ & & & $\begin{array}{l}60(59.4) \\
41(40.6)\end{array}$ \\
\hline Schooling levels & $\begin{array}{l}\text { Elementary school } \\
\text { High School } \\
\text { Illiterate } \\
\text { Post-graduate }\end{array}$ & & & $\begin{array}{l}58(57.5) \\
25(24.8) \\
17(16.8) \\
1(1)\end{array}$ \\
\hline Job & $\begin{array}{l}\text { Retired } \\
\text { Illness pay } \\
\text { Wage labor } \\
\text { Self-employed } \\
\text { Others }\end{array}$ & & & $\begin{array}{c}48(47.5) \\
36(35.6) \\
4(4) \\
2(2) \\
11(10.9)\end{array}$ \\
\hline Income per capita & $\begin{array}{l}\text { Up to } 1 \text { minimum wage } \\
\text { Up to } 2 \text { minimum wages } \\
\text { Up to } 3 \text { minimum wages } \\
\text { No income }\end{array}$ & & & $\begin{array}{l}67(66.3) \\
30(29.7) \\
2(2) \\
2(2)\end{array}$ \\
\hline $\begin{array}{l}\text { Cost of transportation } \\
\text { to the ambulatory } \\
\text { per appointment }\end{array}$ & $\begin{array}{l}\text { Up to } R \$ 50.00 \\
\text { No cost } \\
\text { More than } R \$ 50.00\end{array}$ & & & $\begin{array}{l}45(44.6) \\
37(36.6) \\
19(18.8)\end{array}$ \\
\hline $\begin{array}{l}\text { Monthly costs } \\
\text { of medication }\end{array}$ & $\begin{array}{l}\text { More than } \mathrm{R} \$ 200.00 \\
\text { From } \mathrm{R} \$ 101 \text { to } 200.00 \\
\text { Up to } \mathrm{R} \$ 100.00\end{array}$ & & & $\begin{array}{l}34(33.7) \\
31(30.7) \\
36(35.6)\end{array}$ \\
\hline $\begin{array}{l}\text { Time being } \\
\text { assisted by the } \\
\text { ambulatory }\end{array}$ & $\begin{array}{l}1 \text { to } 5 \text { years } \\
6 \text { to } 10 \text { years } \\
\geq 11 \text { years } \\
<1 \text { year }\end{array}$ & & & $\begin{array}{c}43(42.6) \\
39(38.6) \\
17(16.9) \\
2(1.9)\end{array}$ \\
\hline
\end{tabular}

Table 2 - Clinical data of heart failure patients, Recife, Pernambuco, Brazil, 2017

\begin{tabular}{|c|c|c|c|c|}
\hline Clinical Variable & & Average $\pm S D$ & Variance & n (\%) \\
\hline Etiology & $\begin{array}{l}\text { Idiopathic } \\
\text { Hypertensive } \\
\text { Chagas } \\
\text { Others }\end{array}$ & & & $\begin{array}{l}32(31.7) \\
26(25.7) \\
23(22.8) \\
20(19.8)\end{array}$ \\
\hline Functional Class & $\begin{array}{l}\text { I } \\
\text { II } \\
\text { III }\end{array}$ & & & $\begin{array}{l}43(42.6) \\
39(38.6) \\
19(18.8)\end{array}$ \\
\hline $\begin{array}{l}\text { Ejection } \\
\text { Fraction (EF) }\end{array}$ & $\begin{array}{l}\text { Reduced } \mathrm{EF} \leq 40 \% \\
\text { Intermediate } \mathrm{EF} 41-49 \% \\
\text { Preserved } \mathrm{EF} \geq 50 \% \\
\text { Information not found }\end{array}$ & & & $\begin{array}{l}58(57.4) \\
26(25.5) \\
15(14.9) \\
2(2.2)\end{array}$ \\
\hline $\begin{array}{l}\text { Associated } \\
\text { comorbidities }\end{array}$ & $\begin{array}{l}\text { Systemic arterial hypertension } \\
\text { Dyslipidemia } \\
\text { Diabetes mellitus } \\
\text { Coronary arterial disease }\end{array}$ & & & $\begin{array}{l}75(74.3) \\
49(48.5) \\
27(26.7) \\
17(16.8)\end{array}$ \\
\hline $\begin{array}{l}\text { Medicines } \\
\text { in use }\end{array}$ & $\begin{array}{l}\text { All medications } \\
\text { Cardiologic medications }\end{array}$ & $\begin{array}{l}5,64 \pm 1,79 \\
4,72 \pm 1,39\end{array}$ & $\begin{array}{l}2-11 \\
2-10\end{array}$ & \\
\hline
\end{tabular}


Table 2 (concluded)

\begin{tabular}{llc}
\hline Clinical Variable & Average \pm SD Variance & $\mathbf{n}(\%)$ \\
\hline Medicine class & B-Blockers & $94(93.1)$ \\
& ACE inhibitors/ARBs & $84(83.2)$ \\
& Diuretic & $73(72.3)$ \\
& Potassium-sparing & $54(53.5)$ \\
& Glycoside & $28(27.7)$ \\
& Anticoagulant & $22(21.8)$ \\
\hline
\end{tabular}

Note: $S D=$ Standard deviation; $A C E$ inhibitors = angiotensin-converting-enzyme inhibitors; $A R B s=$ angiotensin receptor blockers.

Table 3 - Classification of Quality of Life Related to Health for heart failure patients, Recife, Pernambuco, Brazil, 2017

\begin{tabular}{|c|c|c|c|c|c|}
\hline & $\begin{array}{l}\text { Good } \\
\text { n (\%) }\end{array}$ & $\begin{array}{c}\text { Moderate } \\
\text { n (\%) }\end{array}$ & $\begin{array}{c}\text { Bad } \\
\text { n (\%) }\end{array}$ & $\begin{array}{l}\text { Total } \\
\text { n (\%) }\end{array}$ & $p$ value \\
\hline \multicolumn{6}{|c|}{ Functional Class } \\
\hline 1 & $34(79.0)$ & $6(13.9)$ & $3(6.9)$ & $43(42.6)$ & \multirow{3}{*}{$<0.001 *$} \\
\hline II & $7(17.9)$ & $18(46.1)$ & $14(35.8)$ & 39 (38.6) & \\
\hline III & $1(5.26)$ & $2(10.5)$ & $16(84.2)$ & 19 (18.) & \\
\hline \multicolumn{6}{|l|}{ Age } \\
\hline$<60$ years & $12(25.0)$ & $15(31.2)$ & $21(43.7)$ & 48 (47.5\%) & \multirow[t]{2}{*}{$0.004^{*}$} \\
\hline$\geq 60$ years & $30(56.6)$ & $11(20.7)$ & $12(22.6)$ & $53(52.5)$ & \\
\hline \multicolumn{6}{|l|}{ Chagas HF } \\
\hline Yes & $6(26.0)$ & $4(17.4)$ & $13(56.5)$ & $23(22.8)$ & \multirow[t]{2}{*}{$0.021^{*}$} \\
\hline No & $36(46.1)$ & $22(28.2)$ & $20(25.6)$ & 78 (77.2) & \\
\hline
\end{tabular}

Note: $S D$ = standard deviation; Chagas $H F=$ patients with heart failure secondary to Chagas disease; * statistically significant difference.

Table 4 - Analysis of average differences among sociodemographic, economic, and clinical variables and the Quality of Life Related to Health for heart failure patients, according to the dimensions of the Minnesota questionnaire, Recife, Pernambuco, Brazil, 2017

\begin{tabular}{|c|c|c|c|c|}
\hline Variables & & $\begin{array}{c}\text { Physical } \\
\text { Dimension } \\
(0-45) \\
\text { Average } \pm \text { SD }\end{array}$ & $\begin{array}{c}\text { Emotional } \\
\text { Dimension } \\
(0-20) \\
\text { Average } \pm \text { SD }\end{array}$ & $\begin{array}{c}\text { Total Score } \\
(0-105) \\
\text { Average } \pm S D\end{array}$ \\
\hline Age & $\begin{array}{l}<60 \text { years } \\
\geq 60 \text { years } \\
p \text { value }\end{array}$ & $\begin{array}{c}18.7 \pm 11.7 \\
10.8 \pm 11.3 \\
<\mathbf{0 . 0 0 1 *}\end{array}$ & $\begin{array}{c}7.6 \pm 5.7 \\
5.5 \pm 5.3 \\
0.06\end{array}$ & $\begin{array}{c}42.3 \pm 20.2 \\
27.0 \pm 20.4 \\
<0.001 *\end{array}$ \\
\hline Income & $\begin{array}{l}\text { No income } \\
\text { Up to } 1 \text { wage } \\
\text { Up to } 2 \text { wages } \\
\text { Up to } 3 \text { wages } \\
p \text { value }\end{array}$ & $\begin{array}{c}37.5 \pm 2.1 \\
15.5 \pm 11.2 \\
10.2 \pm 12.2 \\
25.0 \pm 8.4 \\
0.04^{*}\end{array}$ & $\begin{array}{c}10.0 \pm 8.4 \\
7.1 \pm 5.3 \\
5.0 \pm 5.9 \\
7.0 \pm 2.8 \\
0.317\end{array}$ & $\begin{array}{c}68.5 \pm 14.8 \\
36.3 \pm 19.8 \\
26.7 \pm 23.5 \\
47.0 \pm 5.65 \\
0.017^{*}\end{array}$ \\
\hline Job & $\begin{array}{l}\text { Unemployed } \\
\text { Illness pay } \\
\text { Self-employed } \\
\text { Wage labor } \\
p \text { value }\end{array}$ & $\begin{array}{c}27.8 \pm 15.1 \\
16.9 \pm 10.2 \\
5.0 \pm 4.2 \\
6.2 \pm 8.9 \\
0.01^{*}\end{array}$ & $\begin{array}{c}9.8 \pm 6.8 \\
7.0 \pm 5.1 \\
4.5 \pm 4.9 \\
3.0 \pm 4.2 \\
0.432\end{array}$ & $\begin{array}{c}55.1 \pm 26.4 \\
39.1 \pm 17.3 \\
18.5 \pm 10.6 \\
14.2 \pm 20.0 \\
0.01^{*}\end{array}$ \\
\hline Functional Class & $\begin{array}{l}\text { I } \\
\text { II } \\
\text { III } \\
p \text { value }\end{array}$ & $\begin{array}{c}5.5 \pm 7.1 \\
17.9 \pm 9.2 \\
28.2 \pm 10.3 \\
<\mathbf{0 . 0 0 1 *}\end{array}$ & $\begin{array}{c}4.0 \pm 4.2 \\
7.5 \pm 5.4 \\
10.2 \pm 6.3 \\
<\mathbf{0 . 0 0 1 *}\end{array}$ & $\begin{array}{c}18.6 \pm 14.2 \\
40.5 \pm 17.1 \\
57.0 \pm 17.4 \\
<0.001^{*}\end{array}$ \\
\hline Chagas HF & $\begin{array}{l}\text { No } \\
\text { Yes } \\
p \text { value }\end{array}$ & $\begin{array}{c}13.6 \pm 11.9 \\
17.9 \pm 12.5 \\
0.13\end{array}$ & $\begin{array}{c}5.8 \pm 4.8 \\
9.0 \pm 7.1 \\
0.015^{*}\end{array}$ & $\begin{array}{c}31.8 \pm 21.1 \\
42.8 \pm 21.9 \\
0.021^{*}\end{array}$ \\
\hline $\begin{array}{l}\text { Time being } \\
\text { Assisted by the } \\
\text { ambulatory }\end{array}$ & $\begin{array}{l}<1 \text { year } \\
1 \text { to } 5 \text { years } \\
6 \text { to } 10 \text { years } \\
\geq 11 \text { years } \\
p \text { value }\end{array}$ & $\begin{array}{c}33.5 \pm 7.7 \\
13.9 \pm 11.7 \\
14.7 \pm 12.4 \\
16.4 \pm 12.5 \\
0.119\end{array}$ & $\begin{array}{c}8.0 \pm 11.3 \\
6.3 \pm 5.3 \\
6.7 \pm 5.6 \\
7.4 \pm 6.9 \\
0.896\end{array}$ & $\begin{array}{c}64.0 \pm 21.2 \\
32.7 \pm 22.4 \\
34.7 \pm 20.7 \\
37.9 \pm 22.1 \\
0.243\end{array}$ \\
\hline $\begin{array}{l}\text { Scores per } \\
\text { dimension }\end{array}$ & & $14.6 \pm 12.1$ & $6.56 \pm 5.6$ & $34.3 \pm 21.6$ \\
\hline
\end{tabular}

Note: $S D=$ standard deviation; Chagas $\mathrm{HF}=$ patients with heart failure secondary to Chagas disease; ${ }^{*}=$ statistically significant difference.

\section{DISCUSSION}

The increasing population ageing, high life expectation, and improvements in the treatments of severe cardiopathies has been contributing for the growth in cardiovascular diseases (CVD), among, among them, $\mathrm{HF}$, the final path of most cardiopathies ${ }^{(2)}$. According to this view, the sociodemographic profile of this study was similar to the ones performed in other cardiology ambulatories ${ }^{(10-11)}$

A study that related schooling levels to QLRH has shown that schooling levels are set as an important factor for the QL of heart diseases patients, and it is related to the prevalence of re-hospitalizations and mortality ${ }^{(12)}$. In agreement to a research carried out in Ribeirão Preto, São Paulo, Brazil(13), the schooling levels of this study's sample was up to elementary school. This datum is significant, since low schooling levels could reduce the opportunity for information and access to health care, since it is essential for the communication and for performing the guidelines given by the health team ${ }^{(14)}$.

Unlike the results found in a multicentric study with 1,263 patients, in which ischemic etiology was prevalent in the national scenario as well as in the Northeast region ${ }^{(3)}$, the data in this research show the idiopathic and hypertensive prevalence. A similar research developed in a HF ambulatory in the Brazilian Northeast had also shown idiopathic etiology as the most frequent one ${ }^{(10)}$.

In this research, Chagas disease (CD) was the third most frequent cause of $\mathrm{HF}$, given that it may be related to the functioning, in the ambulatory, of the reference in the state of Pernambuco, for Chagas disease. According to the II Brazilian Consensus on Chagas Disease, the Northeast region is characterized as the second region with the highest prevalence of this disease in the country ${ }^{(15)}$.

In the pharmacological treatment of $\mathrm{HF}$, the most frequently used cardiologic medications were $\beta$-blockers, diuretics, and ACE inhibitors and ARBs, as found in literature ${ }^{(10)}$. A longitudinal study developed in the Netherlands to assess the QLRH of HF patients has found a significant relation between the use of $\beta$-blockers, ARBs and ACE inhibitors in the survival group, throughout the three years of the research. Besides, worst QLRH scores were also related to lower $\beta$-blocker prescription numbers ${ }^{(16)}$.

Also on the medications, it is important to highlight that cardiovascular medications are among the ones that most contribute to polypharmacy ${ }^{(17)}$. The average found in this sample for all medications $(5.64 \pm 1.79)$ was lower than in other studies developed with HF patients $(7.0 \pm 2.0,11.4 \pm 4.3)^{(18-19)}$.

The data analyzed by the Minnesota questionnaire show moderate QL (34.3 \pm 21.6$)$. The averages found were lower than the ones available in national literature $(38.0 \pm 17)^{(20)}$ as well as in the international 
one $(44 \pm 21 ; 34.5 \pm 22.8)^{(16,21)}$. The physical dimension, which assesses the disease's symptomatology, has shown higher scores

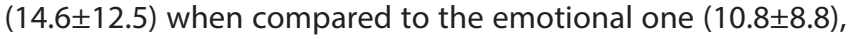
suggesting an important influence of physical alterations, such as dyspnea, fatigue, and edema over the QLRH.

A significant difference was found between age and QLRH in the physical dimension $(p<0.001)$ and in the total score $(p<0.001)$. This result is similar to the one found in a research with $91 \mathrm{HF}$ patients in a ambulatory segment in the municipality of João Pessoa, Paraíba, Brazil ${ }^{(1)}$, in which better QLRH perceptions were shown for older people. Similar studies carried out in São Paulo and Canada have also published similar results, despite regional differences and development indexes ${ }^{(13,22)}$.

The fact that elderly people have a global understanding of the QL concept, articulating knowledge built in their daily lives and in technic-professional experiences, shows the multidimensionality of the QLRH concept for elderly people, and it explains the better scores when compared to younger patients ${ }^{(23)}$.

HF presents a great impact on the worker's health and the symptoms make it harder to perform work duties, demanding changes in function, workload, or even causing occupational inactivity. In agreement to data from a national research ${ }^{(1)}$, in this study, a considerable percentage has declared themselves as professionally inactive, possibly due to the average age of the sample and the precocious physical commitment of HF patients.

The significance found, when related to the occupation and QLRH in the physical dimension $(p=0.01)$ and total score $(p=0.01)$, shows a negative influence on occupational inactivity in the QL of HF patients, specially among the ones that are unemployed and receiving illness pay. The reduction of labor or productive years of $\mathrm{HF}$ patients due to the symptoms may increase costs with medications and negatively affect the QL reported by the patients, in face of the reduction of income per capita ${ }^{(14,21)}$ and family income ${ }^{(24)}$.

The income per capita up to one minimum wage is set as a risk variable for low scores in the physical dimension $(p=0.04)$ and total score $(p=0.01)$, corroborating to what is found in literature $^{(25)}$. Those who declared not possessing any income had almost twice worst QLRH scores, when compared to the ones that have monthly incomes of up to a minimum wage.

The impact caused in QLRH due to low income is related to the difficulty in accessing health services, in acquiring medications, food, and to necessary changes in lifestyle, contributing to rehospitalizations, low therapeutic adhesion, and worse QL scores ${ }^{(14)}$.

In HF ambulatories, it is expected the prevalence of less symptomatic patients, with lower FC and, consequently, better QLRH. Therefore, just as in studies developed in national ${ }^{(1,13)}$ and international ${ }^{(21)}$ ambulatories, the most found FC (NYHA) in the sample were I and II.

The averages obtained showed strong significance between QLRH and FC in all analyzed dimensions, so that the higher the FC is, the worse QLRH is ${ }^{(1,20,24)}$. According to the existing literature, despite being a subjective indicator, the FC allows for the stratification of the limitation degree in daily life activities, having, besides a functional character, the capacity for evaluating the QLRH in relation to $\mathrm{HF}^{(4,19)}$.

The total QLRH average was higher in the group of patients with Chagas HF, when compared to the non-Chagas group, and the emotional dimension was the main contributing factor for these data, showing that the perception of QLRH in the population with Chagas surpasses clinical matters. The emotional impact on patients' lives is connected to cultural stigmas, compared to the ones of chronical diseases discriminated by the current society, such as cancer and the Acquired Immunodeficiency Syndrome (AIDS). It also changes the way of thinking and producing in family and society relations, leading to shifts in behavior patterns ${ }^{(26)}$.

Despite not having found significance between QLRH and the time going to the ambulatory, the patients with less than a year in the service had worse scores in all studied aspects, as well as in other researches, which suggest a positive influence of this variable on these patients' QL perception ${ }^{(10,13)}$.

According to the classification of the European Society of Cardiology, a great percentage of the sample has reduced ejection fraction ( $<40 \%$ ) and, when compared to QLRH scores, there was no significance. Despite these patients' severity, the averages in the evaluated dimensions showed moderate QLRH, a fact that may be related to the multi-professional care offered in the ambulatory.

$\mathrm{HF}$ is considered a debilitating disease due to the reduction of cardiac debit and EF. Thus, when the amount of blood ejected by the left ventricle is not enough to meet body demands, it is possible to occur the exacerbation of physical symptoms, such as dyspnea and fatigue and, consequently, worse QLRH perceptions $^{(1)}$. This affirmation, however, is controversial, since some studies disagree to these findings and do not find any significance among variables, just as it happened in this research ${ }^{(13,20)}$.

A research developed in a HF specialized clinic in the state of Goiás has related negatively the number of medications to $\mathrm{QL}^{(20)}$, while this research has demonstrated a weak correlation only for the physical dimension $(p=0.06)$.

\section{Study limitations}

It is recommended to perform studies approaching the hypothesis that the time being cared for in the ambulatory positively affects the QLRH, and that CD negatively affects the QLRH for HF patients, since the low number of patients with this pathology is set as a limitation of this study.

\section{Contributions to the Nursing, Health, and Public Policy areas}

It is important to highlight that the ways of facing the disease developed by the patients are subjective and that the health team has an essential role on the process of health education and empowering for self-care. To teach HF patients is to help them understand the pathology, the changes needed for better adaptation, for the correct use of therapy, the reduction of complications, decompensation, and hospitalization. To capacitate patients to be the leading role in their health-illness processes is essential to improve their QLRH perceptions.

\section{CONCLUSION}

HF patients' QLRH was considered moderate, with significant relation to age, functional class, and the group of patients with $\mathrm{HF}$ secondary to Chagas disease. The averages were higher for the physical dimension, which reflects the symptoms and limitations caused by the disease, when compared to the emotional dimension. 
The physical dimension was strongly affected by age, and it presented relation to income and occupation. The group of patients with CD presented significant values for the emotional disease, demonstrating the disease's negative influence on the total QLRH score. The FC variable was the only one to present strong significance for all three analyzed dimensions.

\section{ERRATUM}

Article "Quality of life related to health for heart failure patients", with number of DOI: http://dx.doi.org/10.1590/0034-7167-20180368, published in the journal Revista Brasileira de Enfermagem, v72(suppl 2):140-6, on page 142:

The Table 1:

\begin{tabular}{|c|c|c|c|c|}
\hline \multicolumn{2}{|c|}{ Sociodemographic Variables } & \multirow{2}{*}{$\begin{array}{c}\text { Average } \pm \text { SD } \\
60,23 \pm 10,81\end{array}$} & \multirow{2}{*}{$\begin{array}{c}\text { Minimum/ } \\
\text { maximum }\end{array}$} & \multirow[t]{2}{*}{ n (\%) } \\
\hline Age & $\begin{array}{l}\geq 60 \text { years } \\
<60 \text { years }\end{array}$ & & & \\
\hline Gender & $\begin{array}{l}\text { Male } \\
\text { Female }\end{array}$ & & & \\
\hline Race/Color & $\begin{array}{l}\text { Brown } \\
\text { Black } \\
\text { White } \\
\text { Yellow }\end{array}$ & & & $1(1 \%)$ \\
\hline Marital status & $\begin{array}{l}\text { Married } \\
\text { Single } \\
\text { Widow(er) } \\
\text { Divorced }\end{array}$ & & & $8(7.9 \%)$ \\
\hline Precedence & $\begin{array}{l}\text { Metropolitan Region } \\
\text { Other Regions }\end{array}$ & & & \\
\hline Schooling levels & $\begin{array}{l}\text { Elementary school } \\
\text { High School } \\
\text { Illiterate } \\
\text { Post-graduate }\end{array}$ & & & $1(1 \%)$ \\
\hline Job & $\begin{array}{l}\text { Retired } \\
\text { Illness pay } \\
\text { Wage labor } \\
\text { Self-employed } \\
\text { Others }\end{array}$ & & & $\begin{array}{l}4(4 \%) \\
2(2 \%)\end{array}$ \\
\hline Income per capita & $\begin{array}{l}\text { Up to } 1 \text { minimum wage } \\
\text { Up to } 2 \text { minimum wages } \\
\text { Up to } 3 \text { minimum wages } \\
\text { No income }\end{array}$ & & & $\begin{array}{l}2(2 \%) \\
2(2 \%)\end{array}$ \\
\hline $\begin{array}{l}\text { Cost of transportation } \\
\text { to the ambulatory per } \\
\text { appointment }\end{array}$ & $\begin{array}{l}\text { Up to } \mathrm{R} \$ 50.00 \\
\text { No cost } \\
\text { More than } \mathrm{R} \$ 50.00\end{array}$ & & & \\
\hline $\begin{array}{l}\text { Monthly costs } \\
\text { of medication }\end{array}$ & $\begin{array}{l}\text { More than } R \$ 200.00 \\
\text { From } R \$ 101 \text { to } 200.00 \\
\text { Up to } R \$ 100.00\end{array}$ & & & \\
\hline $\begin{array}{l}\text { Time being } \\
\text { assisted by the } \\
\text { ambulatory }\end{array}$ & $\begin{array}{l}1 \text { to } 5 \text { years } \\
6 \text { to } 10 \text { years } \\
\geq 11 \text { years } \\
<1 \text { year }\end{array}$ & & & $2(1.9 \%)$ \\
\hline
\end{tabular}

Replace it with:

\begin{tabular}{|c|c|c|c|c|}
\hline \multicolumn{2}{|c|}{ Sociodemographic Variables } & \multirow{2}{*}{$\begin{array}{c}\text { Average } \pm \text { SD } \\
60,23 \pm 10,81\end{array}$} & \multirow{2}{*}{$\begin{array}{c}\begin{array}{c}\text { Minimum/ } \\
\text { maximum }\end{array} \\
30-79\end{array}$} & \multirow{2}{*}{$\begin{array}{c}\text { n(\%) } \\
53(52.5) \\
48(47.5)\end{array}$} \\
\hline Age & $\begin{array}{l}\geq 60 \text { years } \\
<60 \text { years }\end{array}$ & & & \\
\hline Gender & $\begin{array}{l}\text { Male } \\
\text { Female }\end{array}$ & & & $\begin{array}{l}57(56.4) \\
44(43.6)\end{array}$ \\
\hline Race/Color & $\begin{array}{l}\text { Brown } \\
\text { Black } \\
\text { White } \\
\text { Yellow }\end{array}$ & & & $\begin{array}{c}66(65.3) \\
19(18.8) \\
15(14.9) \\
1(1)\end{array}$ \\
\hline Marital status & $\begin{array}{l}\text { Married } \\
\text { Single } \\
\text { Widow(er) } \\
\text { Divorced }\end{array}$ & & & $\begin{array}{l}58(57.4) \\
19(18.8) \\
16(15.8) \\
8(7.9)\end{array}$ \\
\hline Precedence & $\begin{array}{l}\text { Metropolitan Region } \\
\text { Other Regions }\end{array}$ & & & $\begin{array}{l}60(59.4) \\
41(40.6)\end{array}$ \\
\hline Schooling levels & $\begin{array}{l}\text { Elementary school } \\
\text { High School } \\
\text { Illiterate } \\
\text { Post-graduate }\end{array}$ & & & $\begin{array}{l}58(57.5) \\
25(24.8) \\
17(16.8) \\
1(1)\end{array}$ \\
\hline Job & $\begin{array}{l}\text { Retired } \\
\text { Illness pay } \\
\text { Wage labor } \\
\text { Self-employed } \\
\text { Others }\end{array}$ & & & $\begin{array}{c}48(47.5) \\
36(35.6) \\
4(4) \\
2(2) \\
11(10.9)\end{array}$ \\
\hline Income per capita & $\begin{array}{l}\text { Up to } 1 \text { minimum wage } \\
\text { Up to } 2 \text { minimum wages } \\
\text { Up to } 3 \text { minimum wages } \\
\text { No income }\end{array}$ & & & $\begin{array}{l}67(66.3) \\
30(29.7) \\
2(2) \\
2(2)\end{array}$ \\
\hline $\begin{array}{l}\text { Cost of transportation } \\
\text { to the ambulatory per } \\
\text { appointment }\end{array}$ & $\begin{array}{l}\text { Up to } \mathrm{R} \$ 50.00 \\
\text { No cost } \\
\text { More than } \mathrm{R} \$ 50.00\end{array}$ & & & $\begin{array}{l}45(44.6) \\
37(36.6) \\
19(18.8)\end{array}$ \\
\hline $\begin{array}{l}\text { Monthly costs } \\
\text { of medication }\end{array}$ & $\begin{array}{l}\text { More than } R \$ 200.00 \\
\text { From } R \$ 101 \text { to } 200.00 \\
\text { Up to } R \$ 100.00\end{array}$ & & & $\begin{array}{l}34(33.7) \\
31(30.7) \\
36(35.6)\end{array}$ \\
\hline $\begin{array}{l}\text { Time being } \\
\text { assisted by the } \\
\text { ambulatory }\end{array}$ & $\begin{array}{l}1 \text { to } 5 \text { years } \\
6 \text { to } 10 \text { years } \\
\geq 11 \text { years } \\
<1 \text { year }\end{array}$ & & & $\begin{array}{l}43(42.6) \\
39(38.6) \\
17(16.9) \\
2(1.9)\end{array}$ \\
\hline
\end{tabular}

\section{REFERENCES}

1. Sousa MM, Oliveira JS, Soares MJGO, Bezerra SMMS, Araújo AA, Oliveira SHS. Association of social and clinical conditions to the quality of life of patients with heart failure. Rev Gaúcha Enferm. 2017;38(2):e65885. doi: 10.1590/1983-1447.2017.02.65885

2. Boisvert S, Proulx-Belhumeur A, Gonçalves N, Doré M, Francoeur J, Gallani MC. An integrative literature review on nursing interventions aimed at increasing self-care among heart failure patients. Rev Latino-Am Enfermagem. 2015;23(4):753-68. doi: 10.1590/0104-1169.0370.2612

3. Albuquerque DC, Souza Neto JD, Bacal F, Rohde LEP, Bernardez-Pereira S, Berwanger O, et al. I Brazilian Registry of Heart Failure - Clinical Aspects, Care Quality and Hospitalization Outcomes. Arq Bras Cardiol. 2015;104(6):433-42. doi: 10.5935/abc.20150031 
4. Bocchi EA, Marcondes-Braga FG, Bacal F, Ferraz AS, Albuquerque D, Rodrigues D, et al. Sociedade Brasileira de Cardiologia. Atualização da Diretriz Brasileira de Insuficiência Cardíaca Crônica - 2012. Arq Bras Cardiol [Internet]. 2012 [cited 2017 Oct 17];98(Suppl 1):1-33. Available from: http://publicacoes.cardiol.br/consenso/2012/Diretriz\%20IC\%20Crônica.pdf

5. Calixtre EM, Prado FAA, Almeida E, Fontes GM, Silva KFM, Gemme CN, et al. Reabilitação cardíaca fase III associada à VNI no tratamento da ICC: um estudo de caso. Rev Saúde Meio Ambiente [Internet]. 2017 [cited 2017 Nov 13];4(1):62-76. Available from: http://seer.ufms.br/index. php/sameamb/article/view/1994/pdf_13

6. Oliveira BG, Abreu MNS, Abreu CDG, Rocha MOC, Ribeiro AL. Health-related quality of life in patients with Chagas disease. Rev Soc Bras Med Trop. 2011;44(2):150-6. doi: 10.1590/S0037-86822011005000002

7. Oliveira-Campos M, Rodrigues-Neto JF, Silveira MF, Neves DMR, Vilhena JM, Oliveira JF, et al. Impacto dos fatores de risco para doenças crônicas não transmissíveis na qualidade de vida. Ciênc Saúde Colet. 2013;18(3):873-82. doi: 10.1590/S1413-81232013000300033

8. Carvalho VO, Guimarães GV, Carrara D, Bacal F, Bocchi EA. Validation of the Portuguese version of the Minnesota Living with Heart Failure Questionnaire. Arq Bras Cardiol. 2009;93(1):36-41. doi: 10.1590/S0066-782X2009000700008

9. Vaillant-Roussel H, Laporte C, Pereira B, Tanguy B, Cassagnes J, Ruivard M, et al. Patient education in chronic heart failure in primary care (ETIC) and its impact on patient quality of life: design of a cluster randomised trial. BMC Fam Pract. 2014;15:208. doi: 10.1186/ s12875-014-0208-3

10. Barbosa RR, Franklin RV, Stefenoni AV, Moraes VD, Jacques TM, Serpa RG, et al. Análise da qualidade de vida em homens e mulheres portadores de insuficiência cardíaca. Rev Bras Cardiol [Internet]. 2014 [cited 2019 Apr 5];27(2):97-103. Available from: http://www.onlineijcs. com/detalhes/15/quality-of-life-analysis-among-men-and-women-with-heart-failure

11. Saccoman ICRS, Cintra FA, Gallani MCBJ. Fatores associados às crenças sobre adesão ao tratamento não medicamentoso de pacientes com insuficiência cardíaca. Rev Esc Enferm USP. 2014; 48(1):18-24. doi: 10.1590/S0080-623420140000100002

12. Rosa ACM, Lamari NM. Caracterização de pacientes reinternados no setor de cardiologia. Arq Ciênc Saúde. 2017;24(3):79-83. doi: 10.17696/2318-3691.24.3.2017.640

13. Pelegrino VM, Dantas RAS, Clark AM. Health-related quality of life determinants in outpatients with heart failure. Rev Latino-Am Enfermagem. 2011;19(3):451-7. doi: 10.1590/S0104-11692011000300002

14. Almeida GAS, Teixeira JBA, Barichello E, Barbosa MH. Perfil de saúde de pacientes acometidos por insuficiência cardíaca. Esc Anna Nery. 2013;17(2):328-35. doi: 10.1590/S1414-81452013000200018

15. Dias JCP, Ramos Jr NA, Gontijo ED, Luquetti A, Shikanai-Yasuda MA, Coura JR, et al. II Consenso Brasileiro em Doença de Chagas, 2015. Epidemiol Serv Saúde. 2016;25(n. esp.):7-86. doi: 10.5123/s1679-49742016000500002

16. Hoekstra T, Jaarsma T, van Veldhuisen DJ, Hillege HL, Sanderman R, Lesman-Leegte I. Quality of life and survival in patients with heart failure. Eur J Heart Fail. 2013;15(1):94-102. doi: 10.1093/eurjhf/hfs148

17. Silveira EA, Dalastra L, Pagotto V. Polypharmacy, chronic diseases and nutritional markers in community-dwelling older. Rev Bras Epidemiol. 2014;17(4):818-29. doi: 10.1590/1809-4503201400040002

18. Mantovani VM, Ruschel KB, Souza EN, Mussi C, Rabelo-Silva ER. Treatment adherence in patients with heart failure receiving nurse-assisted home visits. Acta Paul Enferm. 2015;28(1):41-7. doi: 10.1590/1982-0194201500008

19. Xavier SO, Ferretti-Rebustini REL, Santana-Santos E, Lucchesi PAO, Hohl KG. Heart failure as a predictor of functional dependence in hospitalized elderly. Rev Esc Enferm USP. 2015;49(5):786-92. doi: 10.1590/S0080-623420150000500012

20. Lima PB, Morais ER. Qualidade de vida e nível de atividade física de pacientes portadores de insuficiência cardíaca crônica. ASSOBRAFIR Ciênc [Internet]. 2014 [cited 2018 Jan 27];5(1):27-39. Available from: http://www.uel.br/revistas/uel/index.php/rebrafis/article/view/17578/14456

21. Chu SH, Lee WH, Yoo JS, Kim SS, Ko IS, Oh EG, et al. Factors affecting quality of life in Korean patients with chronic heart failure. Jpn J Nurs Sci. 2014;11(1):54-64. doi: 10.1111/jjns.12002

22. Seto E, Leonard KJ, Cafazzo JA, Masino C, Barnsley J, Ross HJ. Self-care and quality of life of patients with heart failure in a multidisciplinary clinic of cardiopathies. J Cardiovasc Nurs. 2011;26(5):377-85. doi: 10.1097/JCN.0b013e31820612b8

23. Ferreira MCG, Tura LFR, Silva RC, Ferreira MA. Social representations of older adults regarding quality of life. Rev Bras Enferm. 2017;70(4):80613. doi: 10.1590/0034-7167-2017-0097

24. Sousa MM, Oliveira JS, Soares MJGO, Bezerra SMMS, Oliveira SHS. Physical and psychosocial effects of heart failure in perceived quality of life. Cogitare Enferm. 2017;22(2):e49783. doi: 10.5380/ce.v22i2.49783

25. Vagetti GC, Moreira NB, Barbosa Filho VC, Oliveira V, Cancian CF, Mazzardo O, et al. Domínios da qualidade de vida associados à percepção de saúde: um estudo com idosas de um programa de atividade física em bairros de baixa renda de Curitiba, Paraná, Brasil. Ciênc Saúde Colet. 2013;18(12):3483-93. doi: 10.1590/S1413-81232013001200005

26. Gomes LMX, Santos AC, Lima FR, Barbosa TLA, Teles JT. The impact of Chagas' disease in daily patient. Motricidade [Internet]. 2012 [cited 2017 Nov 29];8(Suppl 2):204-11. Available from: http://www.redalyc.org/pdf/2730/273023568024.pdf 